\title{
LEVEL OF COMMUNITY PARTICIPATION IN LAKSANA TOURISM VILLAGE, IBUN DISTRICT, BANDUNG REGENCY, WEST JAVA, INDONESIA
}

\author{
Serly Anjelia, Endah Djuwendah, Elly Rasmikayati, Hepi Hapsari \\ Universitas Padjadjaran, Indonesia \\ serlyanjel@gmail.com
}

\begin{abstract}
Laksana Tourism Village has the potential to become a better tourist destination. The situation shows that the management of community-based tourism villages is not good enough. This study aims to determine the level of community participation. This study uses a quantitative approach with survey techniques. The object analyzed is the community involved in tourism activities. The data analyzed are the results of interviews, questionnaires, literature studies, and field documentation. Research data were analyzed using descriptive statistics with a Likert scale. The results of this study are that community participation in the Tourism Village at the planning stage is still dominated by external parties and certain groups of people, at the implementation stage it involves almost the entire community, the utilization stage of the results shows there is a clear profit sharing but not yet transparent report, and at the evaluation stage there is no continuous evaluation.
\end{abstract}

Keywords: Participation rate; Tourism Village; Community.

\section{INTRODUCTION}

Indonesia is an archipelago that has biodiversity potential that has the opportunity to be developed as a tourist attraction. The beginning of the development of agriculture-based villages into an agro-tourism object in Indonesia was recorded in the Directorate General of Tourism data in 1994/1995, wherein the data recorded 8 provinces that have agro-tourism objects, namely North Sumatra, Riau, West Java, Central Java and DIY, East Java, West Nusa Tenggara, Central Kalimantan and West Kalimantan. West Java Province is one of the areas in great demand as one of the top lists as a family vacation destination, besides Bali and Yogyajarta.

This is in line with West Java BPS Data (2019) which shows an increase in visits every year in the last 5 years, namely in 2014 visited by 48.894823 people, in 2015 visited by 57,401,977 people, in 2016 visited by 60.483381 people, in 2017 visited by $61,682,389$ people, and in 201865.896063 people were visited. In a smaller scope, Bandung Regency in 2016 ranks first with the highest number of visits in the province of West Java $(6,450,468$ people), and dropped to fourth in 2017 (3,964,181 
people). The Chairman of PHRI said the decline in domestic visits was due to infrastructure development on the Jakarta-Cikampek toll road, while foreign visits declined due to lack of innovation from tourist destinations and the occurrence of competition with other countries in Asia (Halim, 2017).

Bandung Regency has a natural beauty that attracts visitors to recreation. The high number of visitors is supported by the existence of a tourist village. As noted in Bandung Regent Decree number 556.42/Kop.71-Dispopar/2011 there are 9 villages that have the status of tourism villages, where 7 villages are of agroecotourism type and 2 villages are of art and culture tourism type. One of them is Desa Laksana, which is commonly known as Kamojang. The tourism potential at this location is the geotourism of Kawah Kamojang which has been known since 1910 (Rachmat, 2011). The development of tourism in the Laksana Village resulted in the achievement as a winner in the category of healthy tourism arrangements at the Regency/City LOKUS(special location) at the national level (Prodjo, 2019).

According to Cooper (1995) in Sunaryo (2013), the framework of tourism development consists of 5 main components, namely 1) attractions, 2) Accessibility, 3) Aminity, 4) Public Facilities and 5) Institutional. Laksana Village has fulfilled each of the above components, such as tourist attractions with the Kawah Kamojang, cultural tourism with traditional musical and martial arts performances, artificial tours in the presence of Si Anyar Kamojang, has access to the Bandung-Garut road and public transportation to the end of the village Kamojang, available lodging, mosques, and places to eat as a tourist support facility, and has several organizations/community groups as implementing activities.

According to Nur (2018) tourism development is a promising market opportunity economically and can be a source of livelihood for the people in the tourist area, and is also expected to be the main economic driver for the village. According to Haryanto (2014) the development of tourism in Indonesia is felt to focus more on economic and aesthetic values related to the scale of the industry, compared to the values of cultural, social, and environmental wisdom of the community. In line with this, the government also has not put indicators of tourism success in terms of welfare, participation, and satisfaction of the community around the location of attractions that are directly related to tourists.

One key to achieving the goal of developing community-based tourism is community participation. Mikkelsen (2003) defines participation as a voluntary contribution from the community an activity with the aim to achieve changes made by the community itself. Uphoff, et al, 1979 (in Sulistiyorini et al., 2015) explained the stages of participation, namely, 1) the planning stage, the involvement of the community in preparing the activity plan, 2) the implementation phase, the involvement of the community in all forms of participation which was the key to the success of a plan, 3 ) the stage of enjoying the results, as a benchmark for the success of program planning and implementation, 4) the evaluation phase, feedback from a program. Research by Dewi (2013) entitled "Development of Tourism Villages Based on Local Community Participation in Jatiluwih Tourism Villages, Tabanan, Bali" found that in community-based tourism management is still dominated by the role of government, and community-based tourism development has not yet been realized, where community participation is not optimal, the community still acts only as an object of development, not yet the subject of 
development. So to achieve the success of a community-based tourism development program requires more community participation. Another research, Oktami \& Arief (2018) with the title "Community Participation in the Development of Ecotourism Forest Park Ir. H. Djuanda" explained the result that the community agreed that ecotourism must meet the indicators of community involvement, ecology, conservation, education, culture, and visitors satisfaction. However, community involvement is still considerated low, so strategies are needed to existing strengths and opportunities.

According to the managing staff of Laksana Village, the management of the tourism area has several obstacles, including community understanding related to the concept of a tourist village, the weak branding of tourist sites, and the lack of synergy between the parties involved. First, in line with the statement of the Department of Tourism and Culture (Bandung District Regulation No. 4 of 2019) states that the challenge for tourism today is the low participation of the community will be aware of tourism. The concept of Laksana Tourism Village is communitybased tourism, the community's lack of understanding can result in a lack of community participation and participation in tourism activities. Secondly, the tourism object in this area, which is centered in Kamojang Hamlet, is mistakenly perceived by the general public. Where, people generally recognize Kanojang as a tourist attraction in Garut Regency. Administratively, the location should belong to Bandung Regency. Third, the lack of synergy between groups of organizations, as well as with institutions connected with tourism villages such as fostering companies and government components.

The purpose in this study is to measure the participation of local communities in tourism activities in their villages. Based on this, to achieve optimal community-based Tourism Village development, both in terms of management and development, this progress is the responsibility of all stakeholders in tourism development, especially people who live around tourist sites.

\section{METHODOLOGY}

This research uses quantitative design with a case method. Quantitative research is based on the positivism view, where quantitative methodelogy is used to measure and analyze based on research procedures (Sugiyono, 2012). The research technique used is a survey technique. According to Gulo (2002), survey is a method of collecting data in the form of respondents' responses from the sample using research instruments.

Variables are things in the form of objects, attributes, properties, and values that have certain variations determined by researchers to draw conclusions (Sugiyono, 2012). The variables in this study are the stages of participation that refer to Uphoff (1979) and the research variable of Dewi (2013) and Oktami \& Arief (2018). Calculation of the level of participation used a Likert Scale as a reference value then the conclusions using the formula Riduwan (2002), which determines the level of score with the calculation of categories per variable. 
Table 1. Operationalizationof Variables

\begin{tabular}{cccc}
\hline Concept & Dimention & Variable & Indicator \\
\hline Community & Planning Stage & Development & Likert Scale \\
\cline { 2 - 4 } Participation & & Travel program & Likert Scale \\
\cline { 2 - 4 } & Implementation & Suitability & Likert Scale \\
\cline { 2 - 4 } & stage & Role Clarity & Likert Scale \\
\cline { 2 - 4 } & & Program Continuity & Likert Scale \\
\cline { 2 - 4 } & The Stage of & Transparency & Likert Scale \\
\cline { 2 - 4 } & Enjoying Result & Clear Sharing of & Likert Scale \\
& & Result & Likert Scale \\
\cline { 2 - 3 } & Evaluation Stage & Feedback & . \\
\hline
\end{tabular}

The population in this study is the village of Laksana involved in tourism activities consisting of 110 people divided into 8 community groups. Then, using the Slovin formula (Umar, 2005) with a 10\% error limit, obtained 53 samples that will become respondents. The sample in this study will be determined using cluster random sampling, which divides the population of two or more segments based on categories, then a simple random sample is selected, the selected sample will represent each segment (Rahmatina, 2010).

Table 2, Determinations of Respondends

\begin{tabular}{llccc}
\hline No. & \multicolumn{1}{c}{ Type of Group } & $\begin{array}{c}\text { Number } \\
\text { (of people) }\end{array}$ & $\begin{array}{c}\text { Sample } \\
\text { group of people }\end{array}$ & $\begin{array}{c}\text { Rounded } \\
\text { Sample }\end{array}$ \\
\hline 1. & Village Tour Manager & 15 & 6,7 & 7 \\
\hline 2. & Kompepar & 15 & 6,7 & 7 \\
\hline 3. & Karang Taruna & 15 & 6,7 & 7 \\
\hline 4. & Cultural Atractions & 12 & 5,6 & 7 \\
\hline 5. & Culinary Atractions & 15 & 6,7 & 7 \\
\hline 6. & Agriculture & 20 & 9.6 & 5 \\
\hline 7. & Homestay & 10 & 4,6 & 4 \\
\hline 8. & Tour Guide & 8 & 3,7 & 53 \\
\hline & Total & 110 & 53 & \\
\hline
\end{tabular}

In analyzing quantitative data, according to Sugiyono (2012) data analysis is directed to answer the problem formulation in research, such as by using statistical methods. This research will be answered by: 1) descriptive analysis to analyze the results of each instrument in narrative form and summarized in tabulation form, and 2) calculation of the level of score (Riduwan, 2002), where the data is in the form of a Likert scale ( 5 criteria) in the study then concluded the score with the score level formula.

\section{RESULTS AND DISCUSSION}

\section{Overview of Research Locations}

Kamojang's name in the Dutch colonial era was Dano Pateungteung Pangkalan Village, , Paseh Kawedanan Cicalengka District, Bandung Regency, which is generally known as Pangkalan Village. At that time, stood 1 (one) hotel named Grand Hotel (Kamojang Hotel) which was located on the border of 
Pangkalan with Legok Pulus Garut Regency arrowroot with the owner Mr. Heck who is a Dutch citizen. The hotel already has hot water baths, mud baths, craters, visits to the crater, loji (guest registration), several horses as vehicles and campsites in Pangangonan. Exploration carried out by the hotel and its facilities is what became the forerunner of tourism potential.

After the colonial era, the geothermal potential in Kamojang was explored again. In 1970 a mapping of the Kamojang area was carried out and a volcano survey was carried out by experts from New Zealand. Kamojang succeeded in becoming the first Geothermal Power Plant in Indonesia. PT. Pertamina Geothermal Energy (PGE), which operates steam production in Kamojang until 2019, has been operating for 37 years. PT. PGE still let the wells around the crater of Kamojang as a tourist attraction.

In addition to natural potential, the broader scope of Desa Laksana also has other potentials such as art that has been passed down for generations, for example pencak silat which has been studied by local people since 1991 and traditional music buhun, for example kardinding, degung, terbang, dogdog, and calung which was originally used as a repellent on agricultural land or as accompaniment music for traditional ceremonies. This potential was then developed in 2011 in the Bandung Regent's program, which is to develop the potential of village resources in Bandung Regency. Laksana Village was one of the villages highlighted and stipulated in Bandung Regent Decree number 556.42/Kop.71-Dispopar/2011. The basis of the determination of the village is based on the results of research and assessment of various aspects by the Department of Tourism and Sports (District Government Bandung, 2011).

Laksana Village is a village located in Ibun District, Bandung Regency with an area of 1,135.90 ha with a tourism area of 25 ha. The distance from Ibun subdistrict to Laksana Village is $\pm 1.1 \mathrm{~km}$ and the distance from Bandung Regency to Laksana Village is $55 \mathrm{~km}$. The village topology is the slope around the forest (630 ha) where most of the area has the status of a natural tourism park. The average height of the village is 1,200-1,500 meters above sea level and the average rainfall is $781 \mathrm{~mm} /$ year with an average temperature of 210 Celsius (Profile of Laksana Village, 2019).

The main livelihoods for villagers are from the agricultural sector (both as farmers and farm laborers), the industrial sector, and the trade and services sector. The agricultural sector is still the main sector because agricultural land is still a potential sector with an area of 3,432 ha of rainfed agricultural land and 149 ha of dry land agriculture, 166 ha of semi-technical agriculture, and 83 ha of simple agriculture with the types of crops cultivated are arabica coffee, tobacco and vegetables. However, the industrial, trade and other services sectors also showed developments.

\section{Characteristics of Respondents}

Table 3. Characteristics of Respondents

\begin{tabular}{ccccc}
\hline No. & Characteristics & Indicator & Frequency & Percentage (\%) \\
\hline \multirow{2}{*}{1.} & Gender & Male & 47 & 89 \\
\cline { 3 - 5 } & & Female & 6 & 11 \\
\hline 2. & Age & $20-30$ years & 10 & 19 \\
\cline { 2 - 4 } & & $31-40$ years & 19 & 36 \\
\hline
\end{tabular}




\begin{tabular}{|c|c|c|c|c|}
\hline No. & Characteristics & Indicator & Frequency & Percentage (\%) \\
\hline & & $41-50$ years & 13 & 24 \\
\hline & & $50-60$ years & 8 & 15 \\
\hline & & $>60$ years & 3 & 5 \\
\hline \multirow[t]{5}{*}{3.} & Profession & Student & 1 & 2 \\
\hline & & Farmer & 8 & 15 \\
\hline & & Employee & 25 & 47 \\
\hline & & Entrepreneur & 14 & 26 \\
\hline & & Housewife & 5 & 10 \\
\hline \multirow[t]{4}{*}{4.} & Main Income & $<1.000 .000$ & 7 & 13 \\
\hline & & $1.000 .001-2.000 .000$ & 6 & 11 \\
\hline & & $2.000 .001-3.000 .000$ & 13 & 25 \\
\hline & & $>3.000 .001$ & 27 & 51 \\
\hline \multirow[t]{4}{*}{5.} & Additional Income & $<1.000 .000$ & 26 & 49 \\
\hline & & $1.000 .001-2.000 .000$ & 16 & 30 \\
\hline & & $2.000 .001-3.000 .000$ & 5 & 10 \\
\hline & & $>3.000 .001$ & 6 & 11 \\
\hline \multirow[t]{4}{*}{6.} & Training & 0 & 19 & 36 \\
\hline & & $1 \mathrm{x}$ & 10 & 19 \\
\hline & & $2 \mathrm{xx}$ & 4 & 7 \\
\hline & & $3 x$ & 20 & 38 \\
\hline \multirow[t]{4}{*}{7.} & Tourism Experience & $1-3$ years & 28 & 53 \\
\hline & & 4-6 years & 9 & 17 \\
\hline & & $7-9$ years & 10 & 19 \\
\hline & & $>10$ years & 6 & 11 \\
\hline \multirow[t]{2}{*}{8.} & Motivation & Business Opportunity & 25 & 47 \\
\hline & & Increase Knowladge & 28 & 53 \\
\hline \multirow[t]{4}{*}{9.} & Prerequisites & Will & 28 & 53 \\
\hline & Participation & Ability & 13 & 24 \\
\hline & & Chance & 12 & 23 \\
\hline & \multicolumn{2}{|c|}{ Number of Respondents } & 53 & 100 \\
\hline
\end{tabular}

Communities involved in activities in the Laksana Tourism Village are dominated by men who act as field implementers, and the remaining women (11\%) play a role in village-specific agro-tourism and culinary. In the age variable, the community is dominated by early adulthood to old age, which does not involve adolescents under the age of 20 years because most adolescents in Laksana Village are urbanizing the surrounding areas such as Majalaya District, Samarang District, and other areas to continue their education.

The existence of a tourism village opens the opportunity for the community to get additional income, in accordance with the concept of a tourism village which aims to be the driving force of an area's economy. However, it can be seen in table 3 that the people involved in the tourism village activities have not fully benefited financially. where $49 \%$ of respondents get additional income below Rp. 1,000,000, this group is the management of the organization that has less role in tourist services. While $11 \%$ of respondents received additional income of more than Rp. $3,000,000$, this group is a traditional culinary businessman and management that actively manages group tourist activities.

\section{Level of Community Participation}

The level of community participation is measured used a Likert Scale. According Sugiyono (2012), Likert Scale can be used to measure the attitudes, 
opinions, and perceptions of a person or group of people about a social phenomenon. The questionnaire scores from the respondents are summed, and this number is the total score that will be interpreted as the positions of the respondents on a Likert Scale.

To make conclusions from the Likert Scale the formula for determining the level of scores is used by calculating the categories per variable, i.e: (Riduwan, 2002)

1. Determine the minimum index value $=\min$ score $x \sum$ questions $x$ L respondents

2. Determine the maximum index value $=\max$ score $x \sum$ questions $x$ Vrespondents

3. Determine the interval $=\frac{\sum \text { questions }(\max \text { score }-\min \text { score }) x \sum \text { respondents }}{\sum \text { category }}$

Participation is a form of involvement in the form of a process. To distinguish each process, Sumarto 2003 used a benchmark in the form of level of participation which is grouped into 3 (three) parts, that is 1) High is community participation independenly from the planning to evaluation stages; 2) Medium is community participation in a series of stages, but still dominated by certain group of people; 3) Low is the participation of the community is limited to providing input for consideration and depends on other parties.

Table 4. Community Participation in The Tourism Village Laksana

\begin{tabular}{|c|c|c|c|c|c|c|c|c|}
\hline \multirow[b]{2}{*}{ No. } & \multirow[b]{2}{*}{ Variable } & \multicolumn{5}{|c|}{ Criteria } & \multirow[b]{2}{*}{$\begin{array}{l}\text { Score } \\
\text { Total }\end{array}$} & \multirow[b]{2}{*}{ Category } \\
\hline & & $\begin{array}{c}\text { Strongly } \\
\text { Disagree } \\
\text { (1) }\end{array}$ & $\begin{array}{c}\text { Disagree } \\
\text { (2) }\end{array}$ & $\begin{array}{c}\text { Not } \\
\text { Agree } \\
(3)\end{array}$ & $\begin{array}{c}\text { Agree } \\
\text { (4) }\end{array}$ & $\begin{array}{c}\text { Strongly } \\
\text { Agree } \\
\text { (5) }\end{array}$ & & \\
\hline \multicolumn{9}{|c|}{ Planning Stage } \\
\hline 1. & $\begin{array}{l}\text { Village } \\
\text { Tourism } \\
\text { Development } \\
\text { Planning }\end{array}$ & 6 & 26 & 43 & 55 & 29 & 552 & Medium \\
\hline 2. & $\begin{array}{l}\text { Travel } \\
\text { Program } \\
\text { Planning }\end{array}$ & 4 & 10 & 55 & 66 & 24 & 573 & Medium \\
\hline \multicolumn{9}{|c|}{ Implementation Stage } \\
\hline 3. & $\begin{array}{l}\text { Program } \\
\text { Suitability }\end{array}$ & 0 & 0 & 36 & 47 & 23 & 411 & High \\
\hline 4. & Role Clarity & 0 & 2 & 21 & 37 & 46 & 445 & High \\
\hline 5. & $\begin{array}{l}\text { Program } \\
\text { Continuity }\end{array}$ & 3 & 30 & 55 & 39 & 32 & 544 & Medium \\
\hline \multicolumn{9}{|c|}{ The Stage of Yield Utilization } \\
\hline 6. & $\begin{array}{l}\text { Transparancy } \\
\text { of Result }\end{array}$ & 0 & 4 & 69 & 6 & 27 & 374 & Medium \\
\hline 7. & $\begin{array}{l}\text { Clear } \\
\text { Division of } \\
\text { Result }\end{array}$ & 0 & 4 & 33 & 70 & 52 & 647 & Medium \\
\hline \multicolumn{9}{|c|}{ Evaluation Stage } \\
\hline 8. & $\begin{array}{l}\text { Travel } \\
\text { Evaluation }\end{array}$ & 0 & 136 & 16 & 7 & 0 & 348 & Low \\
\hline
\end{tabular}

1. Planning Stage

Basically the development of the Laksana Tourism Village was started by the government. Where in 2011, Dispopar together with the Regent of Bandung designed the Laksana Village based on the results of an institutional study (Online 
Publication of Bandung Regency, 2011). This is different from the process of planning a village to become a tourist village in another location, for example in the results of study Santika (2017) in the Jembak Kab Tourism Village. Semarang, stated that this village began the process of developing the village into a tourism village based on the ideas of the community together with the village administration which was then submitted to the dispopar and socialized to the general public. The difference in this foundation, is possible to be the cause of the lack of citizen participation in the understanding of tourism villages as well as their involvement in development.

The programs implemented by the Tourism Villages are based more on the ideas of stakeholders outside the community who play a role in the tourism villages, such as the Bandung Regency Government or CSR Tourism Villages namely PT. PGE and PT. IP So that in general, people are in a position to accept and implement only programs. However, based on the results of interviews with CSR parties, the form of aid programs is open, people who have ideas are allowed to submit to the company. For example, heavy equipment assistance in the process of developing Anyar Kamojang SI, training assistance and the provision of homestay facilities, and procurement of traditional musical instruments is a form of program that originated from the ideas of community groups.

\section{Implementation Stage}

Results Participation at the implementation stage related to program suitability showed a high category. According to respondents, there are some program implementations that are not in accordance with the plan, such as the location of PKEK which is planned to be built around the Cengseng village, but in its implementation it was built in the village of Sukakarya District. Samarang It is also related to the improvement of the Kamojang Crater tourist area which is considered not in accordance with the principle, where there are several gazebo built permanently. Nevertheless, almost all respondents stated that they still participated in the program carried out by the tourist village.

Results Participation at the implementation stage related to role clarity shows a high category. According to respondents, projects related to the village tourism program usually only involve the core management or the pioneers of the tourism village. However, in its implementation everyone already has a clear role and in accordance with their respective abilities.

Results Participation at the implementation stage related to program continuity shows moderate category. In this variable, the indicators studied are tourism sustainability, tourism promotion, and participation in training / counseling. The community considers that the application of sustainable tourism has not been implemented, due to lack of understanding related to the way the principles of sustainable tourism are applied in the planning process. In his research, Sutiarso (n.d.) stated the principles of sustainable tourism development, including 1) the environment as a long-term tourism asset, 2) tourism was introduced as a positive activity that provides mutual benefits between the environment, the community and tourists, 3) the relationship between tourism with the environment must be managed so that it does not damage resources, and can be accepted / enjoyed by future generations, 4) tourism activities must pay attention to the scale, character, and nature, where tourism activities take place, 5) build harmony between tourists, the 
environment, and local communities , 6) adapting to changes, and 7) cooperation between the tourism industry, local government, and non-governmental organizations to both care and realize these principles. Sutiarso also said that to develop sustainable and community-based ecotourism, an integrated management system is needed, which will involve a planning, implementation, monitoring and evaluation system that is able to integrate all stakeholder interests.

As for the training program related to tourism workers, there are still many people who have not been moved to participate in these activities, so they are usually only attended by representatives of community groups. Similar to the results of study Oktami \& Arief (2018), which stated that the training program that was held was not yet fully successful, due to the attitude of the community who wanted to get material benefits without trying more. In his research, Dwiningrum (2016) states that one of the factors that can inhibit community participation is lazy, apathetic, and unwilling to make changes at the community member level.

\section{The Utilization Stage}

Community participation in the utilization stage of the results related to the transparency of the results of the tourism village program was motivated by the assessment of disagreement. In table 4, it can be seen that the majority of the people consider it less in terms of receiving tourism program reports (score 193), as well as their participation in the presentation of the results of the tourism village program (score 181). This is because there is no clear administrative system related to reporting every activity, and the lack of good management and communication between stakeholders involved in village tourism activities.

Community participation in the utilization stage of results related to the sharing of results from the implementation of the rural tourism program shows a moderate category. Each product offered already has a fixed price. Sharing is usually done by sharing profits ranging from $10-20 \%$ between product owners (ODTW, homestay, culinary, and arts attractions) and service sellers (intermediaries such as event organizers). In this case, a clear management system has not yet been established related to the distribution of results through tourism village institutions / organizations so that the institution / organization has not yet received a percentage of the proceeds for cash or operations. However, from the results of interviews the community claimed to benefit from the existence of tourism activities in his village. This is in line with research Oktami \& Arief (2018) which shows that the results of community participation in Djuanda Tahura ecotourism are quite high, where people can benefit from the exchange of information and insights from the process of interaction with visitors, as well as financial benefits that amount will adjust to the ability and involvement of the community in tourism.

\section{Evaluation Stage}

The results of participation show the value is included in the category of low-level participation with a score of 348. This is because there are no routine evaluation activities, either periodic evaluations or evaluations per activity program. Usually input is only conveyed verbally on certain occasions, not in a forum that was deliberately created to evaluate the program. In connection with the evaluation stage in Tahura Djuanda ecotourism, in the study of Oktami \& Arief (2018) said that community involvement in the evaluation phase is low, where the 
evaluation forum is conducted by the Tahura only, and will produce policies that will later have to be carried out by the implementers of ecotourism including the community . in addition, the results of research Dewi (2013) related to community participation in supervision and evaluation of the development of tourism villages showed low results because the village development planning was carried out by the government, so that the community was not competent to supervise or evaluate.

\section{CONCLUSION}

Tourism Potential in Laksana Village has been known and began to be utilized since 1910, namely tourist destinations from the natural potential of Kamojang Crater. Over time, the completeness of existing tourism, such as traditional culture, agricultural skills, and culinary specialties of the village became another potential which was then developed together in the concept of a tourist village. Until, in 2011, Laksana Village was approved as one of the tourist villages in the Regency. Bandung.

Community participations in the tourism village at the planning stage is still dominated by external parties and certain groups of people, at the implementation stage it involves almost the entire community, the utilization stage of the results shows there is clear provit sharing but not yet at the transparent reporting stage, and at the evaluation stage there is no continuous evaluation.

\section{SUGESTION}

Based on the results and discussion in this study, the researcher suggests several things, as follows.

1. Tourism Village initiates a meeting or deliberation with all stakeholders in the Laksana Tourism Village.

2. Organizational groups in the Tourism Village create a management system, administrative system and coordination line between institutions involved in stakeholders in the Laksana Tourism Village.

\section{REFERENCE}

Bandung District Regulation No. 4 of 2019, (2019).

Bandung Regent Decree number 556.42/Kop.71-Dispopar/2011, (2011).

BPS. (2019). Statistics West Java 2019.

Dewi, M. H. (2013). Development of Tourism Villages Based on Local Community Participation in Jatiluwih Tourism Village, Tabanan, Bali. Kawistara Journal, 3(2), 117-226.

District Government Bandung. (2011). Defined 10 Tourism Villages. Bandung Regency Government. http://www.bandungkab.go.id/arsip/ set-1 villagetourism

Dwiningrum. (2016). Management Conflict between Managers and Communities in Tahura Juanda. JUMPA, 2(2), 111-123.

Gulo, W. (2002). Research Methodology. Grasindo.

Halim, H. (2017). The Worst Tourist Drop in Bandung. Media Pikiran Rakyat. www.pikiranrakyat.com/jawa barat/

Haryanto, T. J. (2014). Ecotourism Development Model in Supporting Regional 
Economic Independence (Case Study of DIY Province). Kawistara.

Mikkelsen, B. (2003). Participatory research method and empowerment efforts. Yayasan Obor Indonesia.

Nur, I. (2018). Implications of Tourism Village Development for Improving the Economy of Local Communities (Study in Pao Village). National Seminar and Call for Paper Management, Accounting and Banking.

Oktami, S., \& Arief. (2018). Community Participation in th Development of Ecotourism in the Great Forest park Ir. H. Juanda. Media Konservasi, 23(3).

Prodjo, W. (2019). Kamojang Crater Area was made a Special Location for Healthy Tourism Regions. Tribun Jawa Barat. https://jabar.tribunnews.com/2019/08/13/

Rachmat, M. (2011). The History of Kamojang. Indonesia Power.

Rahmatina, D. (2010). Procedure Using Stratified Random Sampling Method in Estimating Population Parameters. JEMI Articles, 1(1).

Riduwan. (2002). Measurement Scale of Research Variables. Alfabeta.

Santika, E. (2017). Community Participation and Tourism Village Development in Jambak, Semarang Regency. Scientific Artiicles Universitas Kristen Satya Kencana.

Sugiyono. (2012). Quantitative, Qualitative, and $R \& D$ Research Methods. Alfabeta.

Sulistiyorini, N. R., Darwis, R. S., \& Gutama, A. S. (2015). Community participation in waste management in the Margaluyu Environment of Cicurug Village. SHARE: Social Work Journal, 5(1).

Sunaryo, B. (2013). Development Policy for Tourism Destination Concepts and Its Applications in Indonesia. Gava Media.

Sutiarso, M. A. (n.d.). Development of Sustainable Tourism through Ecotourism. LPBB Mitra Persada.

Umar, H. (2005). Research Methods for Consumer Behavior Services. Ghalia Indonesia.

Uphoff, N. T. (1979). Feasibility and application of rural development participation. 